\author{
بررسى توزيع كربناتها در اجزاى اندازهاى برخى از خاكهاى استان خوزستان \\ سيروس جعفرى '،* مريم كريمزاده' و عباس عبدشاهى

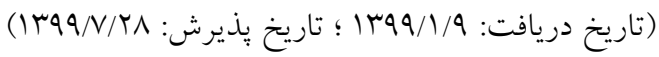

جكيده

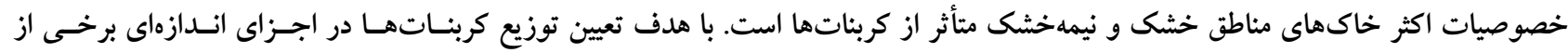

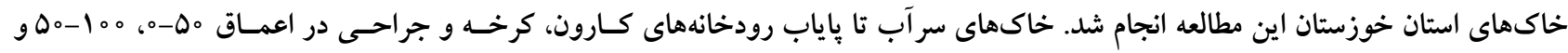

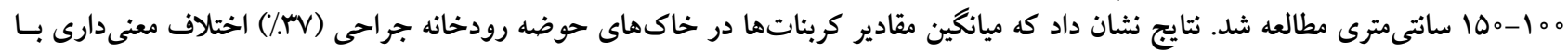

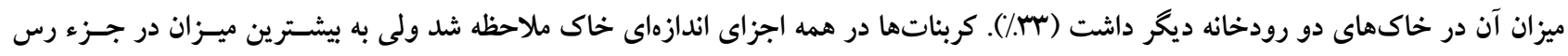

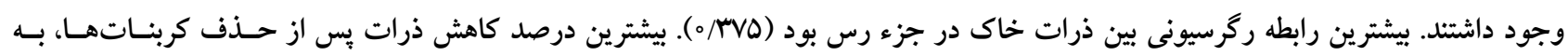

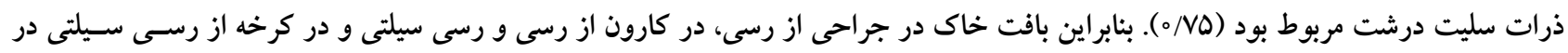

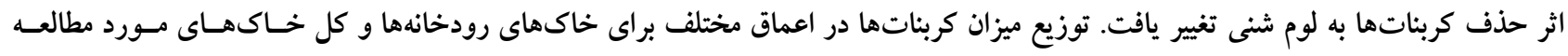

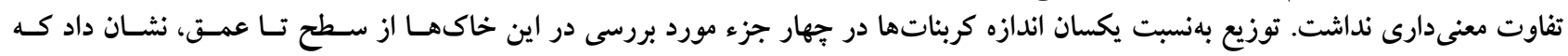

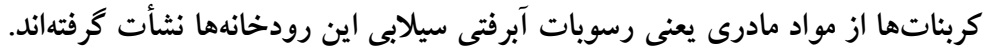

وازههاى كليدى: جراحى، رس، سيلت ريز، كارون، كربنات، كرخه

1. كروه علوم و مهندسى خاك، دانشخاه علوم كشاورزى و منابع طبيعى خوزستان، ملاثانى، اهواز، ايران

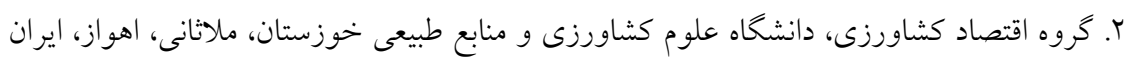
*: مسئول مكاتبات: پِت الكترونيكى: siroosjafari@asnrukh.ac.ir 
شدهاند. جعفرى و ناديان (r) (I) در بررسى رديف پِستى و بلندى

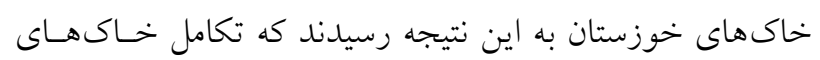

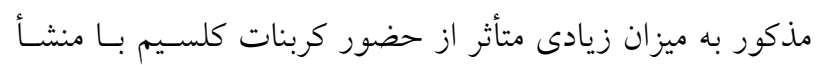

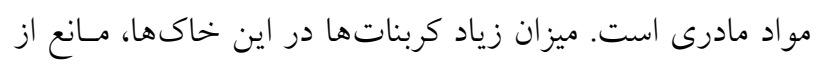

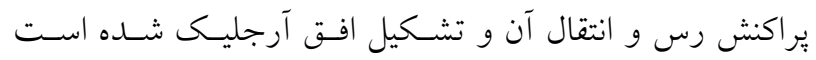

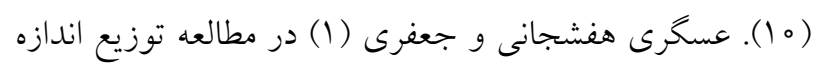

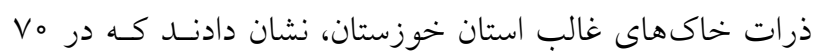
درصد نمونههاى مورد مطالعه قبل و بعد از حسذف كربنـاتهـا،

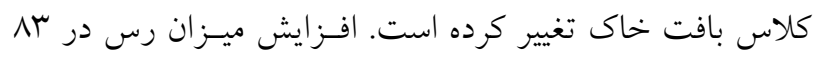

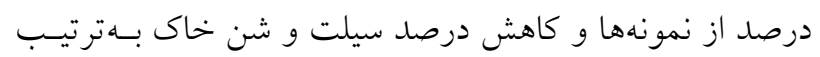

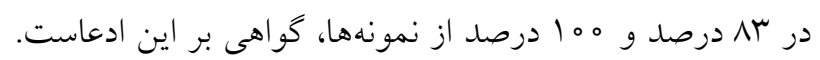

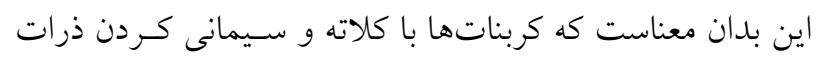

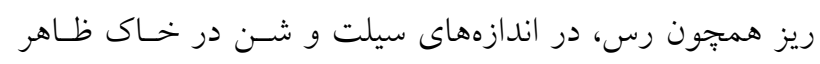

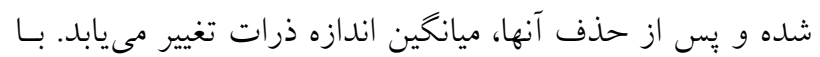

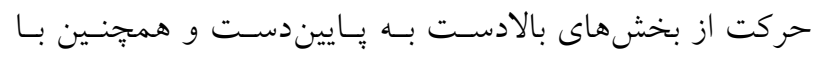

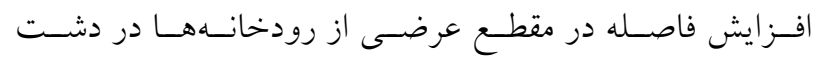

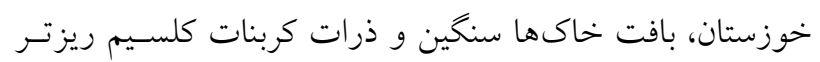

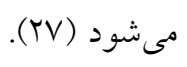

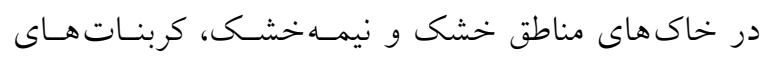
كلسيم و منيزيم بهصورت يوشش كربناتهاى ثانويه و يله هاى كاتيونى، ذرات اوليه خاك را بههم متصل مسى كنتـــ و معمـولاً كلسيم در بهبود ساختمان خـاك اثـرى بيشـتر از منيـزيم دارد نو (YN)

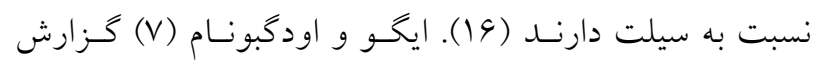

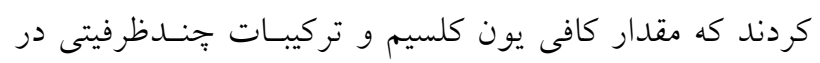

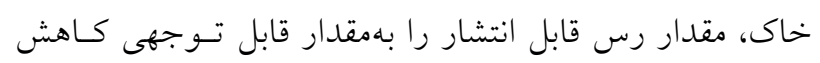

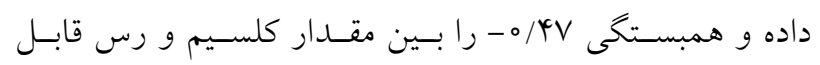

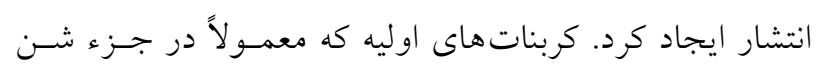

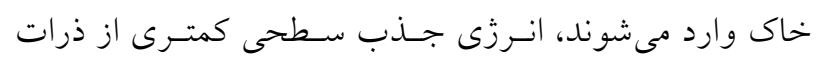

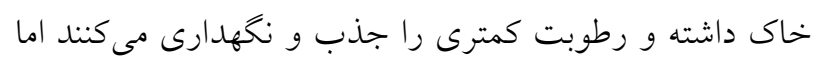

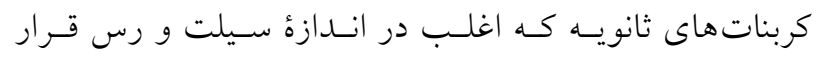

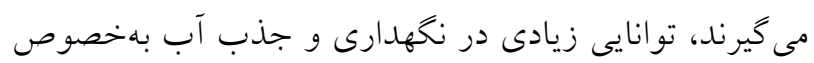

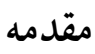

خصوصيات اكثر خاكها در مناطق خشك و نيمهخشـى تحـت

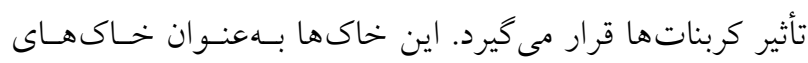

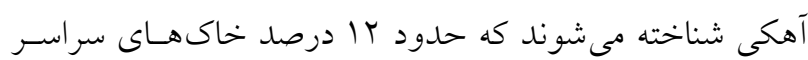

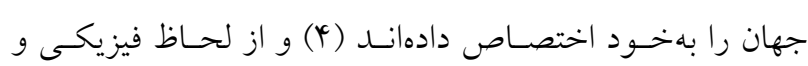

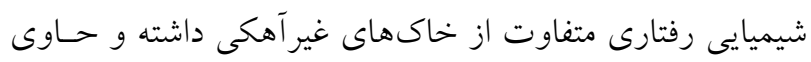

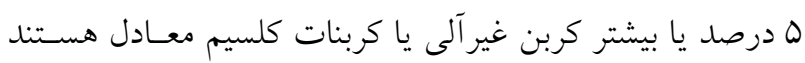

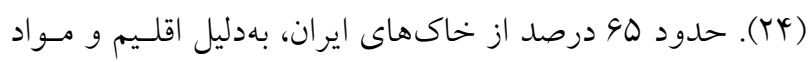

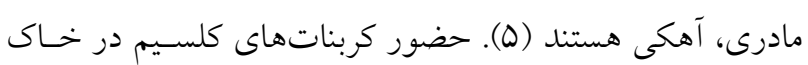

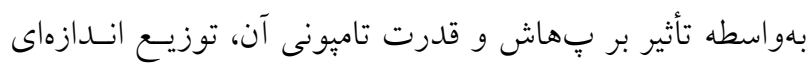

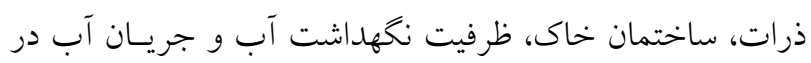

خاى، خصوصيات خاكها را تحت تأثير قرار مىدهد (هات (1).

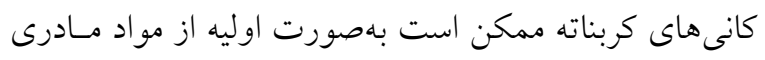

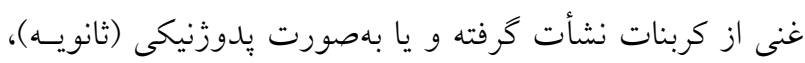

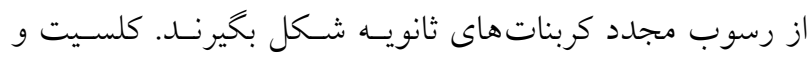

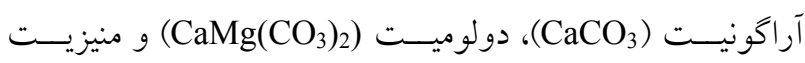
) (MgCO $\left.3{ }_{3}\right)$ خاكهاى آهكى هستند (Y). كلسيت از رايجترين كانى كربناتسه

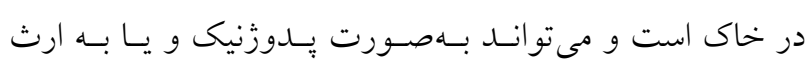

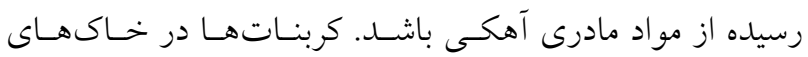

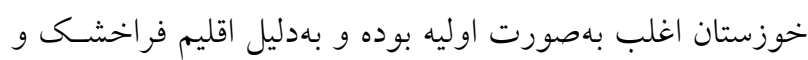
خاى جوان بميزان خيلى كمى آبشويى شدهاند (ه (1).

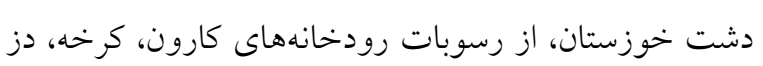

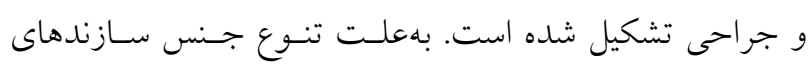

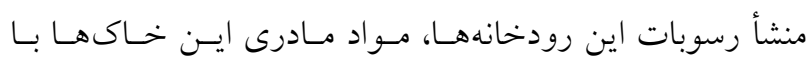

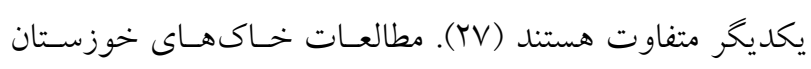

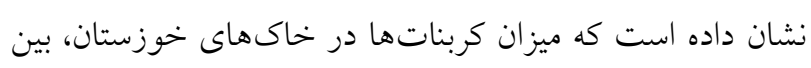

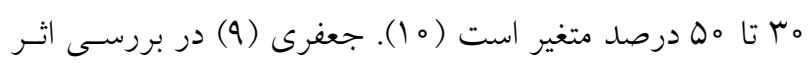

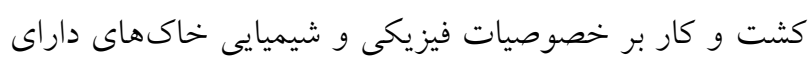

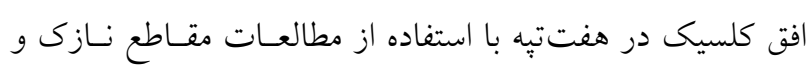

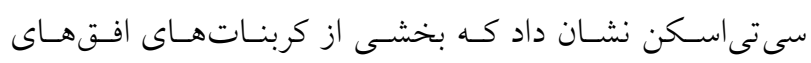

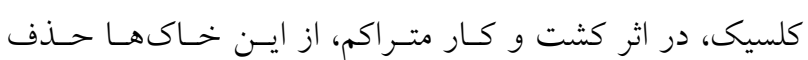


بيشتر متأثر از نمكهاى محلول كلرور سديم است كـه منشـأ آن

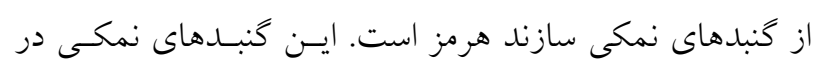

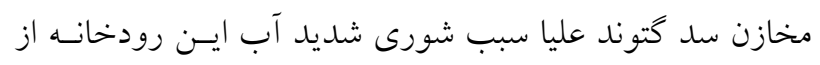

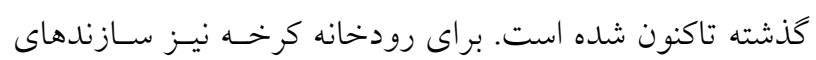

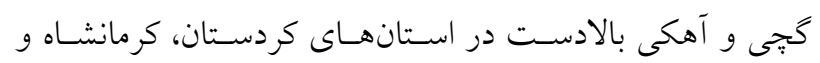

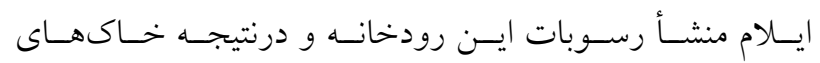

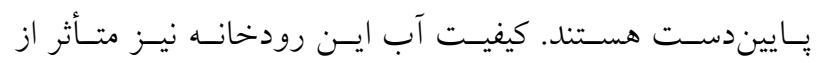
نمكهاى محلول در سـازند كَّسـاران در بالادست اسـت كـهـ

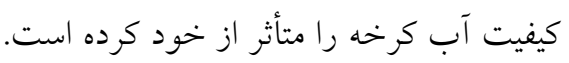

نمونهبردارى خاى در اين مطالعه، با استفاده از نقشههاى تويوگر افى و عكسـهــاى

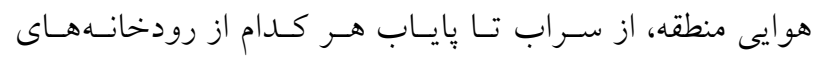

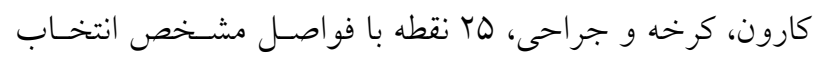

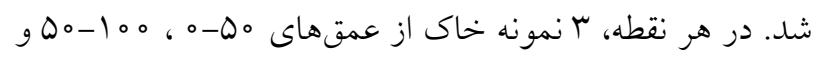

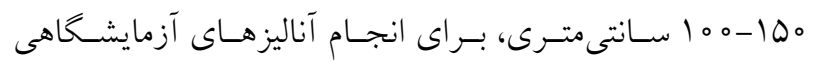

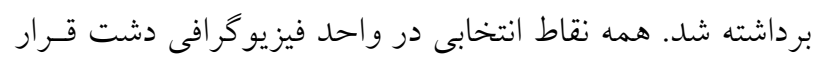

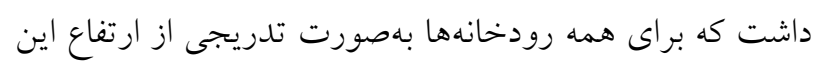

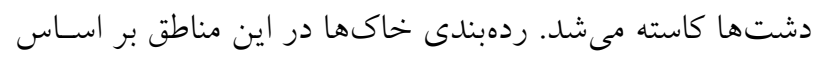

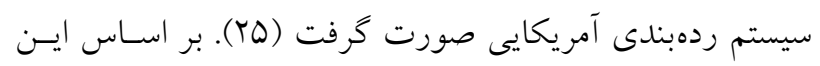

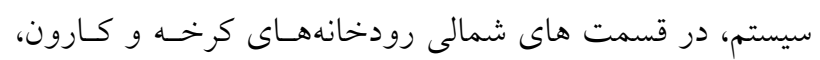

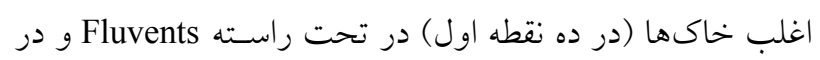

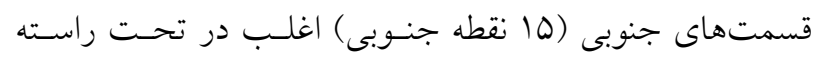
Salids

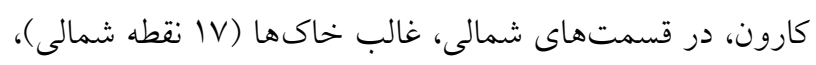

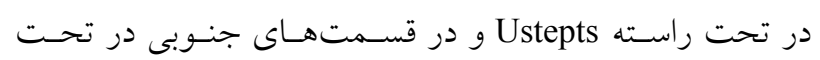

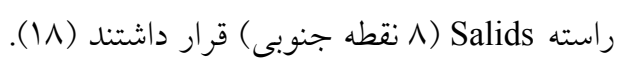

\section{آناليزهاى آزمايشگاهى}

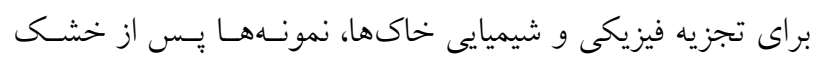

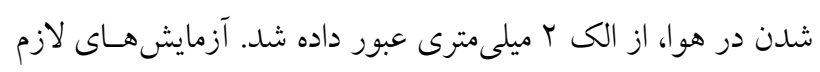

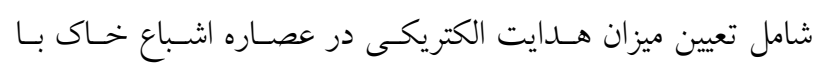

در مكش هاى زياد دارند (19). افزايش ميزان كربناتها موجب

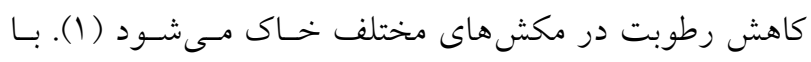

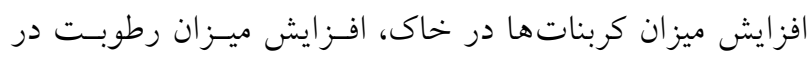

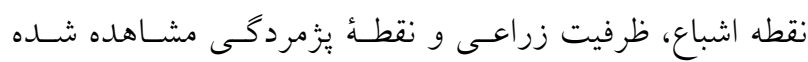

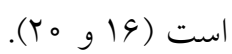
نظر به اينكه تعيين توزيع اندازه ذرات كربناتى و غيركربناتى (براتى

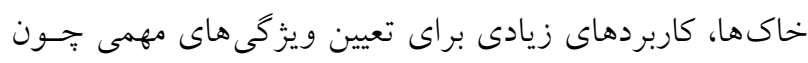

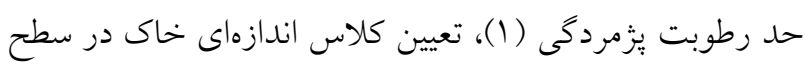

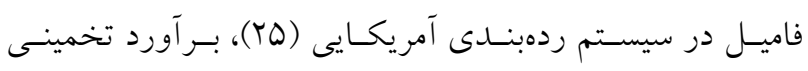

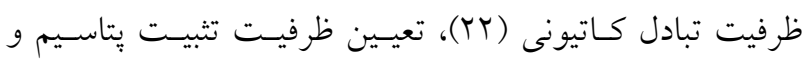

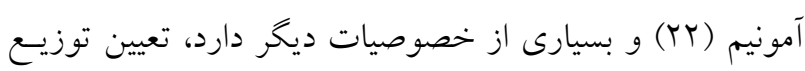

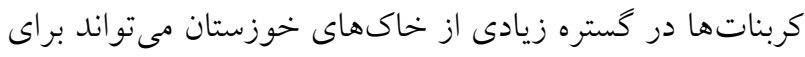

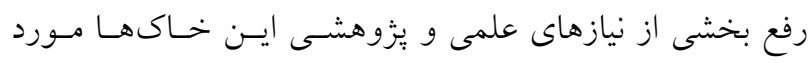

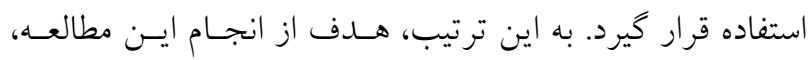

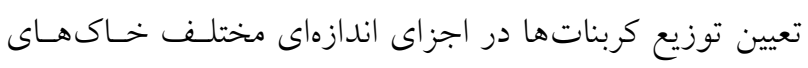
استان خوزستان است.

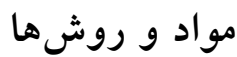
موقعيت منطقه مورد مطالعه

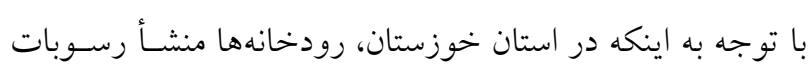

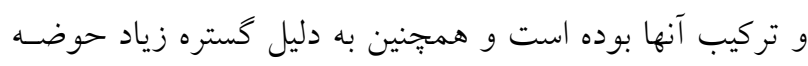

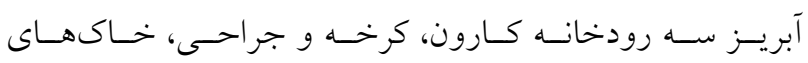

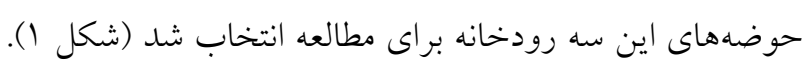

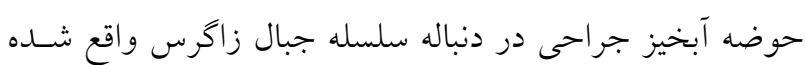

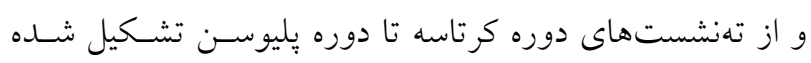

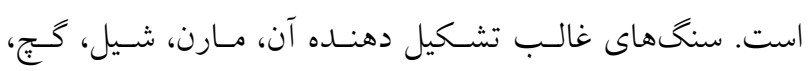

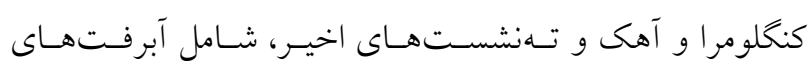
رودخانهاى، دشتهـاى سـيلابى و مخــروطهـاى افكنـه اسـت.

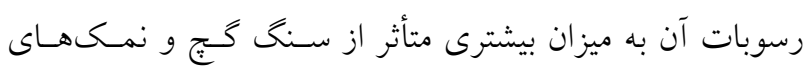

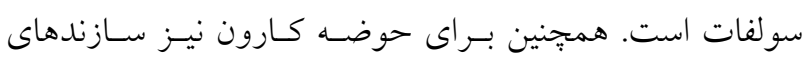

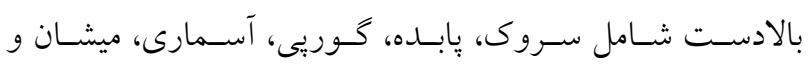
آغاجارى منشأ رسوبات رودخانه است (شكل 1). اين رودخانسه 


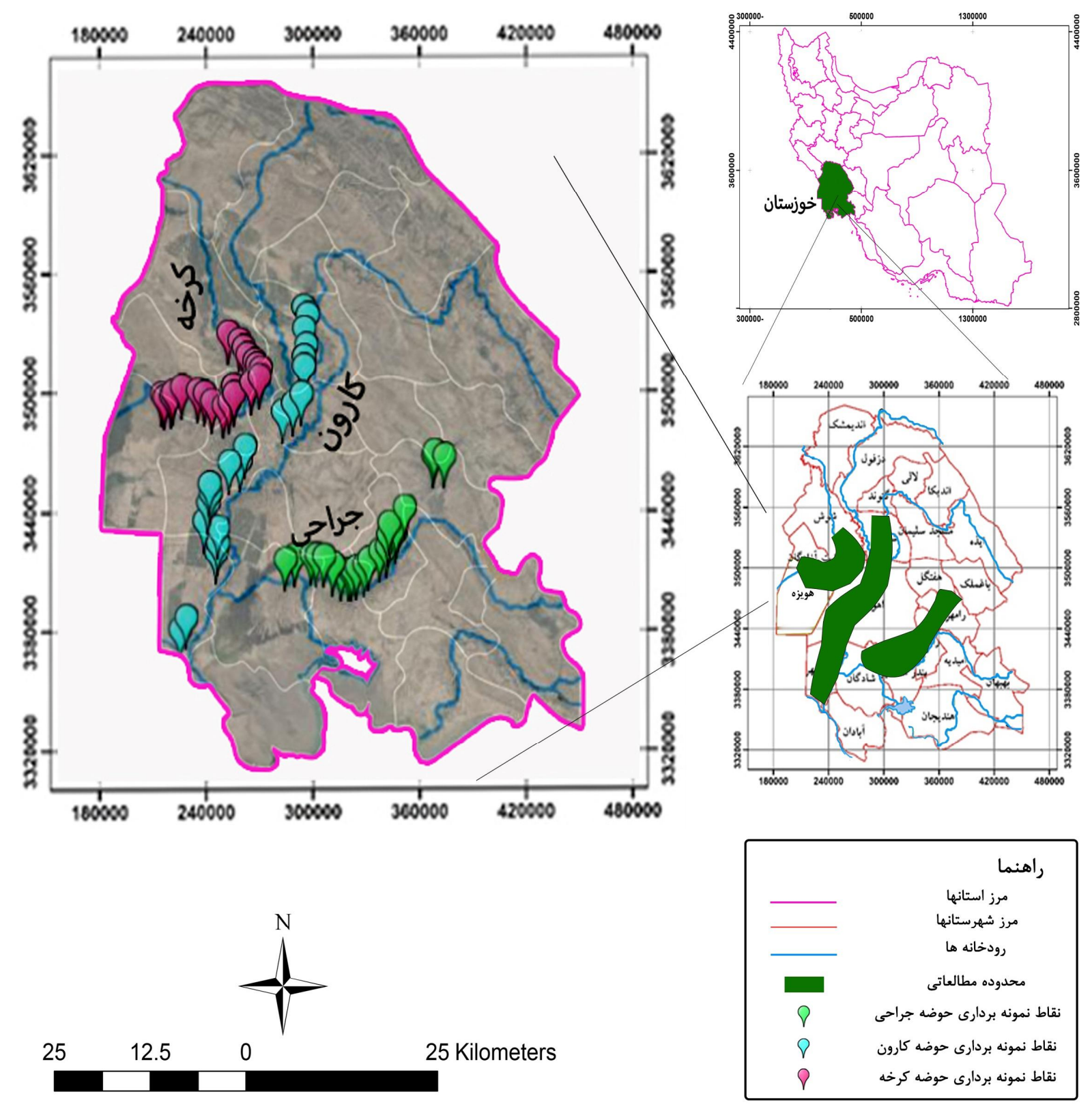

شكل 1. موقعيت نقاط نمونهبردارى شده در خاكهاى حوضهُ رودخانهاى جر احى، كارون و كرخه

روش جكسون (N)، حذف شد. نمونهاى خاك يس از حذف

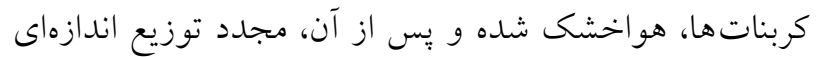

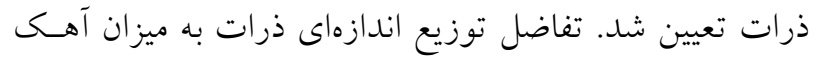

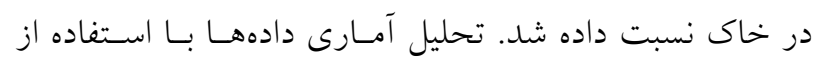

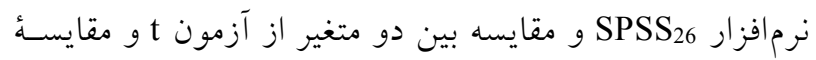

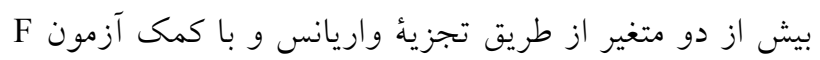
صورت كرفت.
استفاده از دستخاه EC متر، اندازهيرى پِهاش در گـل اشـباع (T) و تعيين ميزان كربنات كلسيم معادل با هضم توسط اسيد

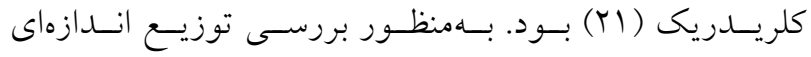
كربناتها در خاك، در مرحلـه اول اجـزاى انــازهاى تشـكيل

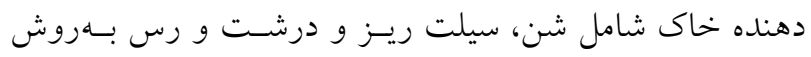

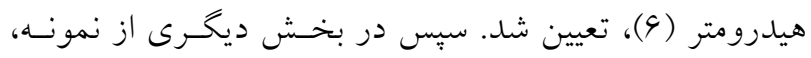

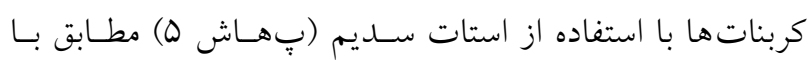


جدول ا. شاخصهاى آمارى خصوصيات خاك در رودخانهاى مورد مطالعه

\begin{tabular}{|c|c|c|c|c|c|c|c|c|c|c|}
\hline ضريب & نما & ميانه & كشيدگى & جولكى & انحراف & تغييرات & ميانخين & تقاطداد & خصوصيت & رودخانه \\
\hline$\circ / V$ & rV & $r V / l$ & Y NT & $-1 / v 9$ & $T Q / 9$ & $r Q / q-r q / \Lambda$ & re/vG & VQ & كربنات (\%) & \\
\hline$\circ / \mathrm{QV}$ & $V / 9$ & $10 / 1$ & $-\circ / V Q$ & $\circ / Q V$ & V/19 & $1 / 4-Y q / r$ & $\mid r / 4 q$ & VQ & شورى (dS/m) & جراحى \\
\hline$\circ / \circ \varphi^{4}$ & $V / \mu$ & $\mathrm{V} / \mathrm{Q}$ & $q / \circ D$ & $-1 / \mathrm{VV}$ & $\circ / \mu y$ & $\Delta / \vee-\Lambda / 1$ & $\mathrm{~V} / 9 \Lambda$ & $V Q$ & $\mathrm{pHe}$ & \\
\hline $0 / \pi 1$ & rN/A & $r \Delta / q$ & $1 / V$ & $-1 / \mu V$ & $V / 4$ & $\Delta / Q-r q / \Delta$ & $r \omega / 9$ & VQ & كربنات (\%) & \\
\hline $0 / 9 T$ & $T / \mu$ & $11 / 9$ & $\% / 0 Y^{x}$ & $0 / 91$ & $19 / \pi$ & $|/ \Gamma-9| / 1$ & $I V / A$ & $V Q$ & شورى (dS/m) & كارون \\
\hline$\circ / \circ \Delta$ & $N / 01$ & $\Lambda / r$ & $-0 / 0 V$ & $-0 / 14$ & $\circ / M V$ & $V / r-\Lambda / q$ & $\Lambda / r$ & $V Q$ & $\mathrm{pHe}$ & \\
\hline $0 / 14$ & my & 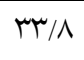 & D/TG & $-1 / 99$ & $r / Q T^{r}$ & $\mid Y / r-r \Lambda$ & rT/V & VQ & كربنات (\%) & \\
\hline O/AY & $1 / 1$ & $19 / V$ & $\circ / 0 \mathrm{~V}$ & $1 / 1 V$ & $r \circ / \wedge D$ & $\circ / 1-\Lambda \uparrow$ & $r Q / \Delta$ & $V Q$ & شورى (dS/m) & كرخه \\
\hline$\circ / \circ \mu$ & $\Lambda / \mu$ & $\Lambda / \mu$ & $\circ / \mathrm{AV}$ & $-0 / 94$ & $0 / 7 q$ & $V / \Delta-\Lambda / q$ & N/Tr & VQ & $\mathrm{pHe}$ & \\
\hline
\end{tabular}

توزيع اندازه ذرات در خاكهاى حوضه رودخانههاى مسورد مطالعه

تغييرات بافت خاكهاى رودخانه جراحى در مثلث بافت خـاك قبل و بعد از حذف كربناتها، بيانخر تغييرات جشـمخير توزيـع اندازه ذرات در اين دو حالت اسـت (شـكل r- الـف). يسـ از حذف كربناتها، كلاس بافت از رسى به لومى شنى تغيير يافتـه و بيانكر اين است كه غالب كربناتها در حوضه اين رودخانسه، در اندازه رس هستند. بافت اغلب خاكهـاى كربنـاتدار در رودخانسه كـارون، در دامنه لوم با سيلت زياد است. توزيع اندازه ذرات بعد از حـذف كربنات، بهشدت تغيير يافته و به لوم ماسهاى تبديل شـده اسـت (شكل r r- ب). در شكل r مقايسه قسمتهاى الف و ب نشان مىدهد كه بافت خاكهاى دو رودخانه جراحى و كارون قبـل

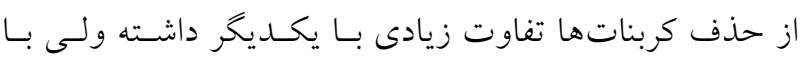
حذف كربناتها، بافتهــاى خـاك دو رودخانـه بـهـ يكـديخر نزديكى و به لوم ماسهاى تبديل شده است. بهعبارتى اخـر جــه كربناتها در اجزاى اندازهاى مختلـف در خـاكهـاى ايسن دو رودخانه توزيع يافتهاند ولى تركيب مـواد غيسركربنـاتى در دو رودخانـه مشـابه هسـتند. مطالعـات مختلـف خاكشناسـى در
نتايج و بحث

خصوصيات فيزيكى و شيميايى خاك حوضه رودخانهها

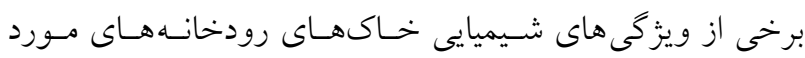

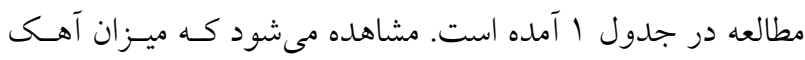

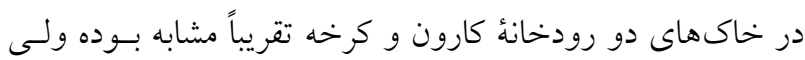
كمتر از مقدار آهك در رودخانه جراحى اسـت. علـت آن را مسى بـ توان به منشأ رسوبات رودخانه جراحى مربوط دانست كـه اغلـب از هواديدگى مارنهاى آهكى بالادست حاصل شده است (جدول (1). بيشترين ميزان شورى در خاكهاى رودخانه كرخه و كمتـرين

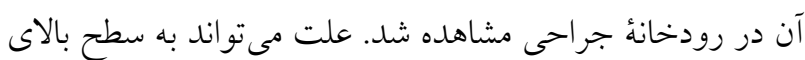
آب زيرزمينى در بخش هاى انتهايى خاكهـاى ايسن رودخانـه، در محدوده يايينتر از شهرهاى سوسنخرد و حميديسه مربسوط باشـــ. كرخه تنها رودخانه خوزستان است كه انتهاى آن وارد دريـاى آزاد نمىشود و به هورالعظيم وارد مىشود. زهـش جـانبى آب تـالاب هور العظيم (هويزه) و تبخيـر آن از اراضسى سـيلابكيـر انتهـيى، عامل شورى بيشتر اين اراضى است. كمترين ميزان pH نيز متعلق به رودخانه جراحى اسـت كـه ممكـن اسـت بسهوجــود تركيبـات

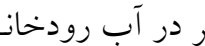
بو لفاته بيش

مربوط باشد. 

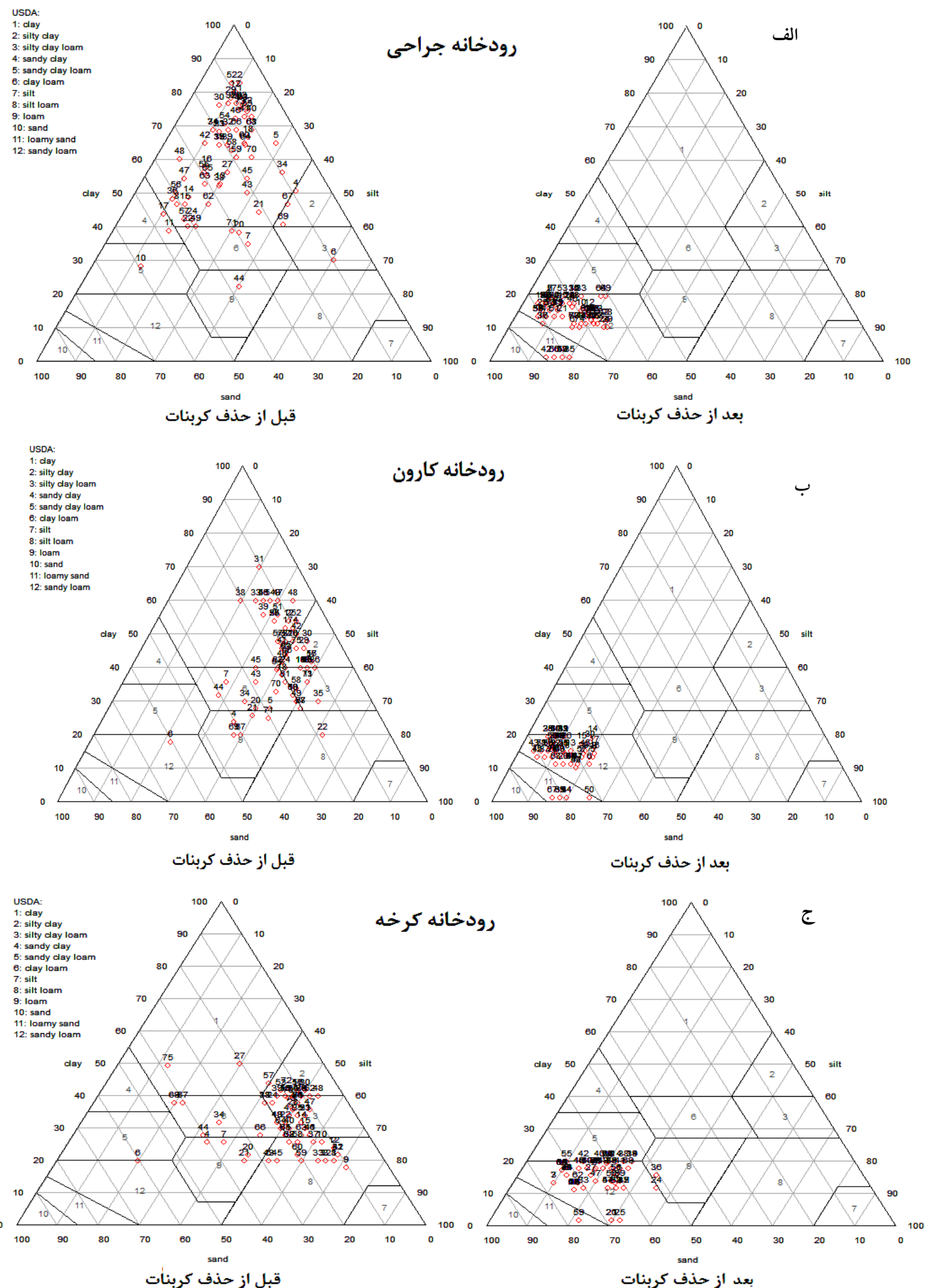

شكل r. تغييرات كلاس بافت خاكهاى حوضه رودخانهاى مورد مطالعه قبل و بعد از حذف كربناتها 
جدول r. مقايسه ميانخين متغيرها در حوضه رودخانهها در اعماق مورد مطالعه

\begin{tabular}{|c|c|c|c|c|c|c|c|c|c|}
\hline \multicolumn{3}{|c|}{ رودخانه كرخه } & \multicolumn{3}{|c|}{ رودخانهُ كارون } & \multicolumn{3}{|c|}{ رودخانه جراحى } & \multirow{3}{*}{ حذف حتفها قبل و بعد از } \\
\hline & F آماره F & ميانخين & سطح & F آماره F & ميانخين & سطح & F آماره F F & ميانخين & \\
\hline معنى دارى & & & معنى دارى & & & معنى دارى & & & \\
\hline $0 / 99$ & $0 / 01$ & $M 1 / 1$ & $\circ / 09$ & $\circ / 09$ & $41 / 9$ & O/YT & $1 / 0$ & $r \circ / V$ & رس قبل \\
\hline D & - /AF & $11 / 0$ & $0 / 99$ & $0 / 01$ & $19 / 9$ & $\circ / V Y$ & س & $\mid V / x$ & رس بعد \\
\hline $0 / 09$ & $r / 9 \Lambda$ & $V / \circ D$ & $\circ / 09$ & - $/ 0 T$ & $\mid r / 4$ & $\circ / V q$ & D & $\mid r / \mu$ & سيلت ريز قبل \\
\hline.$/ 09$ & . $/ \Delta T$ & $r / q$ & $\circ / 09$ & . $/ 0 T$ & $r / q$ & $\circ / \Delta r$ & $0 / 94$ & $r / 9$ & سيلت ريز بعد \\
\hline$\circ / \Delta \Lambda$ & $\circ / \Delta \Delta$ & ҐА/ & $\circ / \mathrm{VV}$ & $0 / r V$ & $r V / 4$ & $\circ / N$ & $0 / \mu 1$ & $r \omega / \varphi$ & سيلت درشت قبل \\
\hline$\circ V^{Y}$ & $0 / \mu 1$ & $11 / \mathrm{V}$ & $\circ / N$ & O MT & $9 / 1$ & $0 / 4 y$ & •/A & $Q / \Lambda$ & سيلت درشت بعد \\
\hline ०/D9 & $0 / 9$ & $11 /\left.\right|^{k}$ & $0 / 91$ & $0 / 49$ & $11 / 9$ & $\circ / 4$ &.$/ 94$ & YI/V & شن قبل \\
\hline $0 / 9 Y$ & $0 / 49$ & $90 / 9$ & $\circ / V$ & ه & $V \mu / 4$ & $0 / 99$ & $\% / 0 Y^{r}$ & $V \Psi / I$ & شن بعد \\
\hline
\end{tabular}

آمارى بين جهار جزء اندازهاى تشكيل دهندهُ خـاى، قبـل و بعد از حذف كربناتها، در اعماق مورد مطالعه مشاهده نشد. در حوضهُ رودخانه جراحى، كمترين سطح معنى دارى متعلق

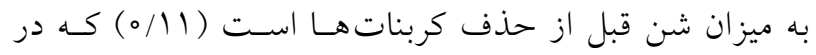

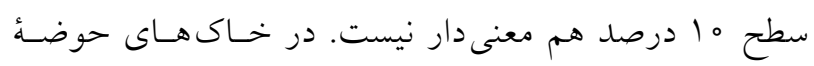

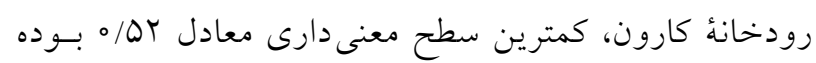

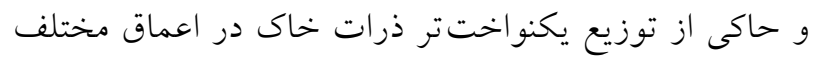

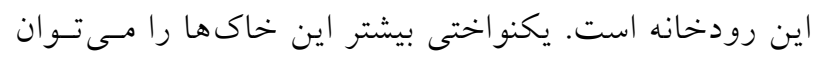

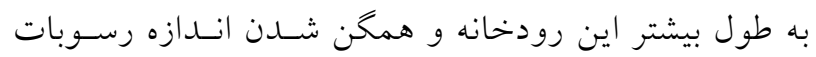

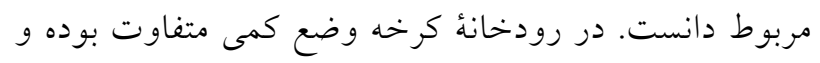

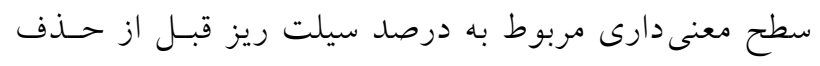

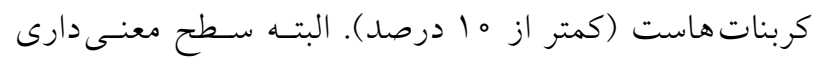
اين متغير هم از سطح معنى دارى قابل قبول (در اين مطالعه.

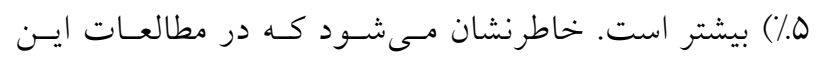
جنينى بيشتر روند تغييرات مهم هستند و كمتـر بـهـ سـطوح

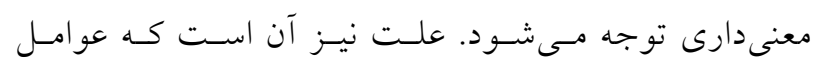

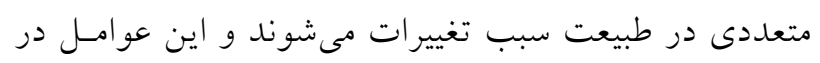

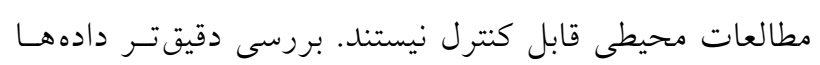

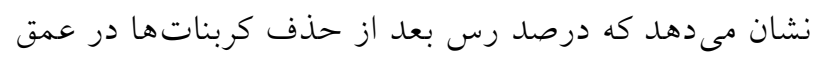
0100-10 بيشتر از دو عمق ديخر است. نكته مهم و اثر خذار
خاكهاى اين دو رودخانه نشان داد كه كربنـاتهـا بـهـهورت اوليه در اين خاكها وجود دارند و افق كلسيك (وجود كربنـات

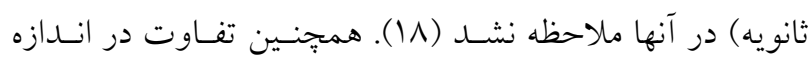

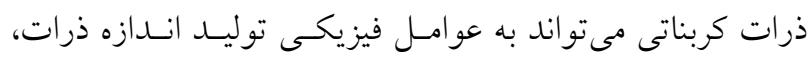

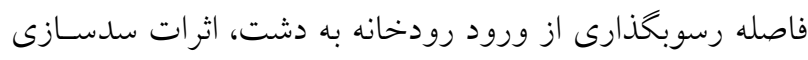

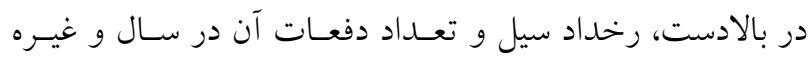
مربوط باشد كه سبب برخى از اين تفاوتها شده است.

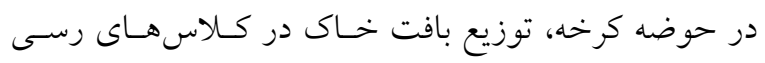

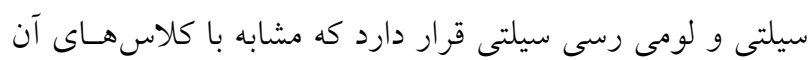
در حوضه كارون اسـت. يـس از حــف كربنـاتهـا، محسـودهد

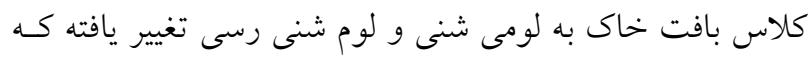
تا حدودى با بافت خـاكهـاى بـدون كربنـات در دو رودخانـه

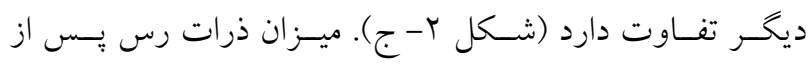
حذف كربناتها، در خاكهاى حوضه كرخه از جراحسى بيشـتر شـه است. بررسى آمارى توزيع اندازه ذرات

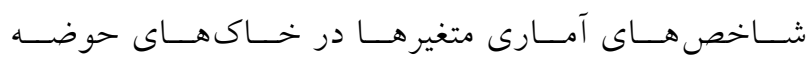
رودخانه هاى مورد بررسى در جدول بآ بآمده است. ملاحظـه.

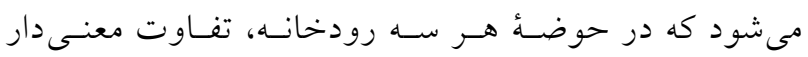


كاهش سيلت درشت در رودخانه جراحى رخ داد.

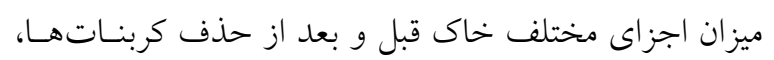

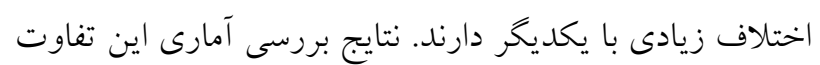

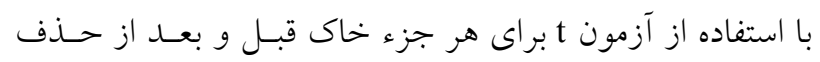

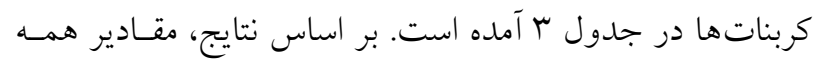

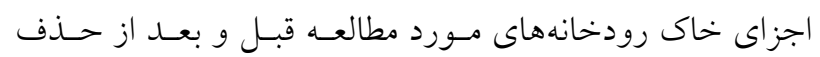

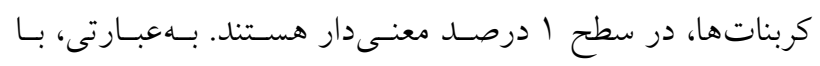
حذف كربناتها، همه اندازهاى ذرات مورد بررسى، در مقايسه

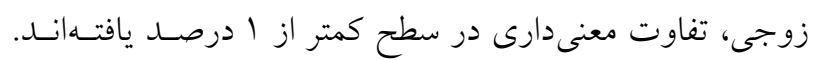

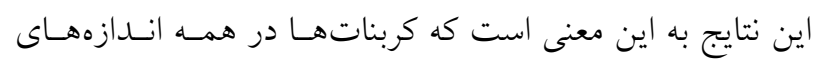

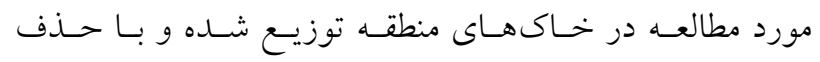

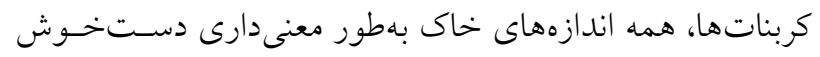

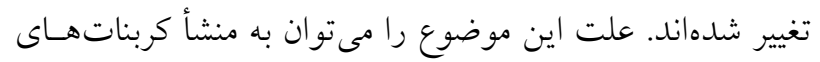

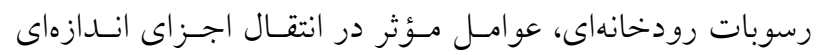

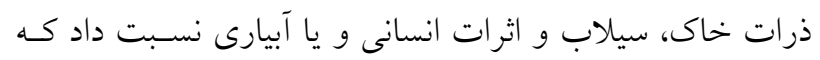

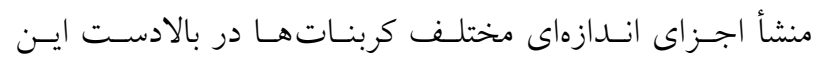

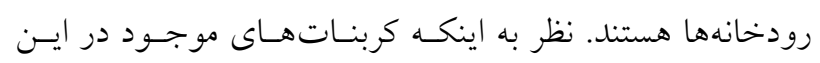

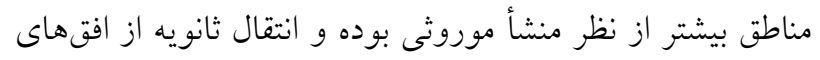

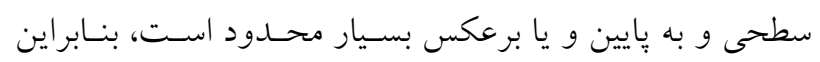

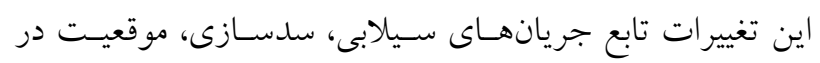

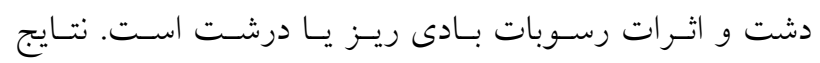

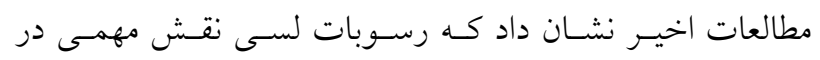

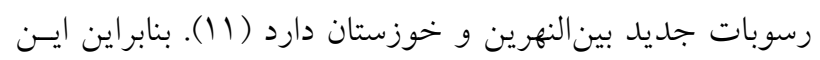

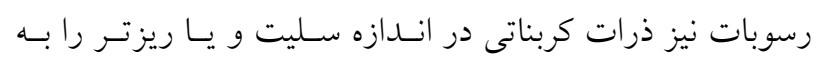
بخشهايى از دشت اضافه كردهاند.

\section{بررسى ويزگىهاى كلى خاكهاى مورد مطالعه}

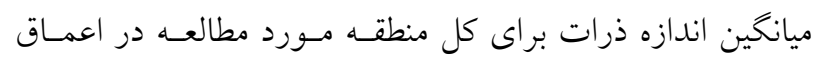
مختلف در جدول \& ارائه شده است. بر اساس نتايج، براى كليـه مئه

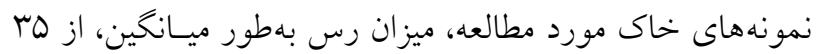

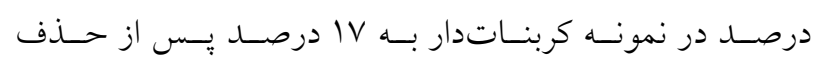

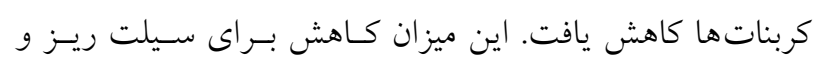

بر اين نتايج اثرات سدسازى بر روند رسوبحذارى در دشـت

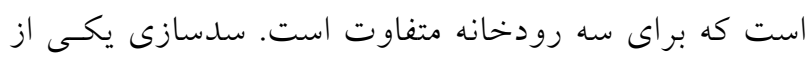
عوامل مهمى است كه بر رخداد سيل در فرودست رودخانسه

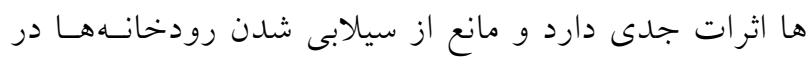

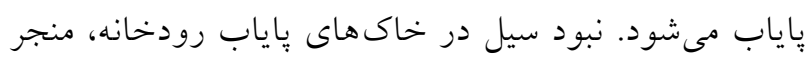

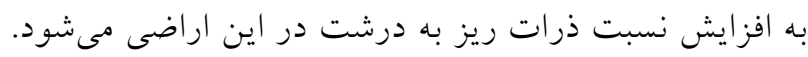

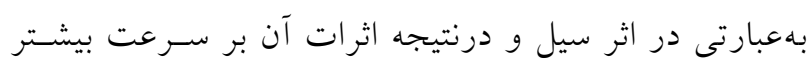

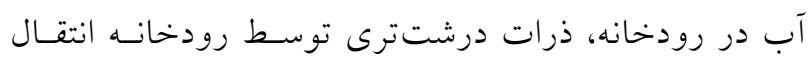

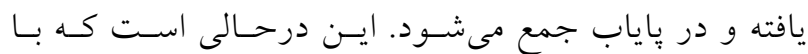

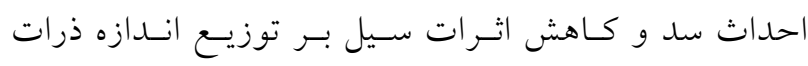

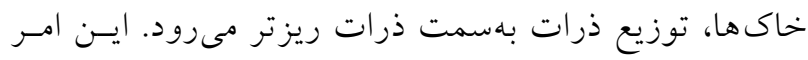

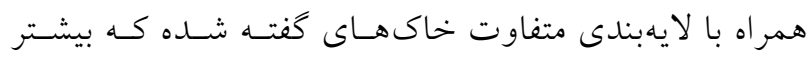

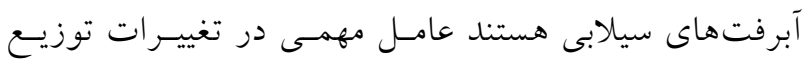

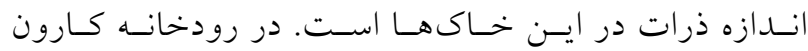

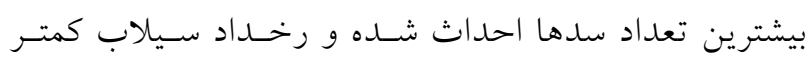
صورت مى گيرد. اين در حالى است كه تا قبل از سال ITVA

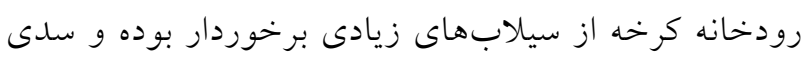

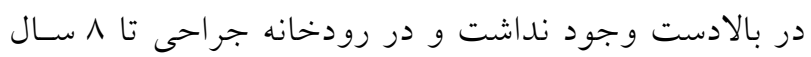
اخير سدى در بالادست احداث نشده بود.

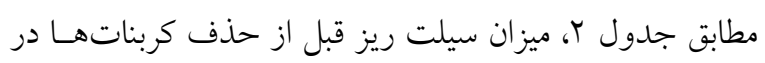

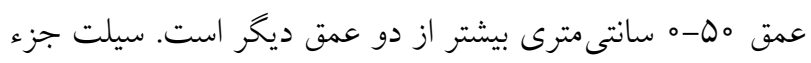

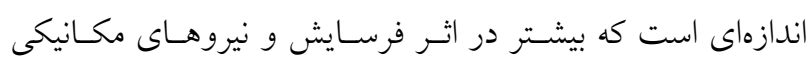

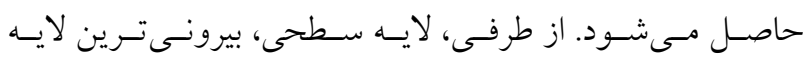

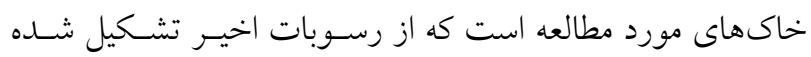
است. بنابراين، اثرات سدسازى و دخالتهاى انسانى بر ايسن لايـهـ

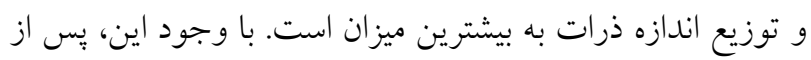

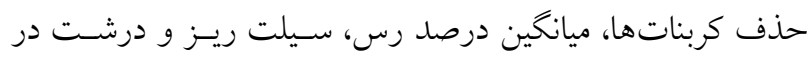
هر سه رودخانه بهطور قابل ملاحظهاى كاهش يافته و نشاندهنـــه

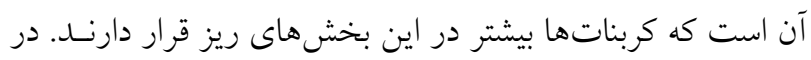

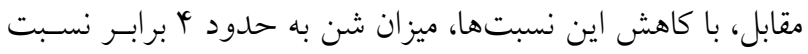

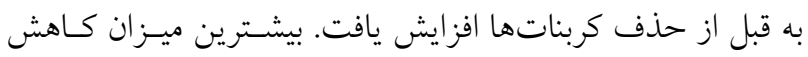
رس در اثر حذف كربناتها، در رودخانه كارون و بيشترين ميـزان 
جدول ب. نتايج آزمون مقايسه مقادير توزيع اندازه ذرات قبل و بعد از حذف كربناتها در رودخانهاى مورد مطالعه

\begin{tabular}{|c|c|c|c|c|c|c|c|c|c|}
\hline \multicolumn{3}{|c|}{ رودخانهُ كرخه } & \multicolumn{3}{|c|}{ رودخانهُ كارون } & \multicolumn{3}{|c|}{ رودخانه جراحى } & \multirow{2}{*}{ متغيرها قبل و بعد } \\
\hline سعنى سطح & t t t t t & ميانخين & معنى دارى & t t t t t & ميانخين & معنى سطحى & t t t t t & اختالفف ميانخين & \\
\hline $0 / 000$ & $\mid r / \mu$ & $1 T / 9$ & $0 / 000$ & $r \circ / 1$ & TQ & $0 / 000$ & $10 / 90$ & $1 \pi / r$ & رس \\
\hline $0 / 000$ & $9 / 4$ & $\mu / \tau$ & ०/००० & $9 / 1$ & $\Lambda / \Delta$ & $0 / 000$ & $9 / 1 r$ & $\Lambda / V$ & سيلت ريز \\
\hline $0 / 000$ & YY/OY & TV & \%००० & $r \circ / r$ & 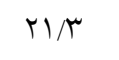 & \%००० & TS/V & $r q / 9$ & سيلت درشت \\
\hline $0 / 000$ & $-r \Delta / \Delta$ & $-Y V / D$ & $0 / 000$ & $-\Delta \circ / T \omega$ & $-Q Y / \Lambda$ & $0 / 000$ & $-M Y / \Lambda Y$ & ه & شن \\
\hline
\end{tabular}

جدول †. ميانخين اندازه ذرات خاك براى كل منطقه مورد مطالعه در عمقهاى مختلف

\begin{tabular}{|c|c|c|c|}
\hline \multicolumn{3}{|c|}{ عمق خاك (سانتى متر) } & \multirow{2}{*}{ 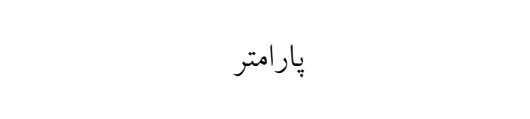 } \\
\hline $100-100$ & $00-100$ & $\circ-\Delta^{\circ}$ & \\
\hline$r y / / \circ a$ & MYV/Ga & rr/ & كربناتها (g/kg) \\
\hline $1 N /\left.\circ\right|^{k} b$ & $\left|N / T^{c}\right| b$ & $19 / \% 9 \mathrm{~b}$ & شورى (dS/m) \\
\hline$V / 90 \mathrm{c}$ & $V / 90 \mathrm{c}$ & $V / 99 c$ & 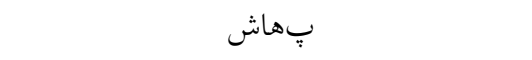 \\
\hline $\mathrm{r \Delta r} / \circ \mathrm{d}$ & d & $\mathrm{MrV} / 9 \mathrm{~d}$ & رس قبل از حذف كربناتها (g/kg) \\
\hline $1 V 9 / 9 \mathrm{e}$ & $\mid V Y / q e$ & $I V / / \Lambda e$ & رس بعد از حذف كربناتها (g/kg) \\
\hline $99 / \mathrm{rf}_{\mathrm{f}}$ & $1.9 / 0 f$ & $1 \circ \wedge / \Delta f$ & سيلت ريز قبل از حذف كربناتها (g/kg) \\
\hline r//lg & $\mathrm{rq} / \mathrm{qg}$ & $\mathrm{r} / \circ \mathrm{g}$ & سيلت ريز بعد از حذف كربناتها (g/kg) \\
\hline$m \mu / r h$ & Myy/Dh & h & سيلت درشت قبل از حذف كربناتها (g/kg) \\
\hline Vq/Vi & $\Lambda \circ / \mathrm{Vi}$ & $V q / \circ \mathrm{i}$ & سيلت درشت بعد از حذف كربناتها (g/kg) \\
\hline $194 / r j$ & $194 / \wedge j$ & $199 / r j$ & شن قبل از حذف كربناتها (g/kg) \\
\hline$\vee \circ \Delta / \Delta \mathrm{k}$ & $V \circ Y / A k$ & $V / 4 / r k$ & شن بعد از حذف كربناتها (g/kg) \\
\hline
\end{tabular}

علائم با حروف انخليسى نشاندهنده معنى دارى در سطح ه درصد هستند.

نتايج مقايسه ميانكين ويز كى هاى خاكهاى سه رودخانسه مـورد مطالعه در جدول ه آمده است. ملاحظه مسىشـود كـه رودخانـأ جراحى داراى بيشترين ميزان كربناتها بوده و تفاوت حسدود ب

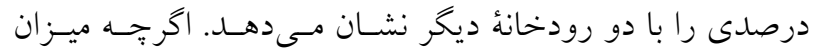
رسهاى كربناتى در رودخانه كارون در حدود ه ا درصـد از دو

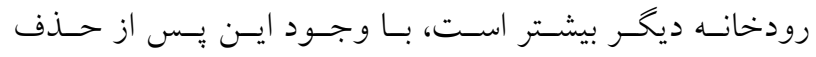
كربناتها، ميزان رس به كمتر از دو رودخانه ديخر كاهش يافتسه است. به اين ترتيب، اين نتايج نشان از آن دارد كه جنس بيشـتر ذرات رس اين رودخانه از تركيبات كربناته است. طول رودخانه
درشت قبل و بعد از حذف كربناتها بهترتيب، از ها و سب به

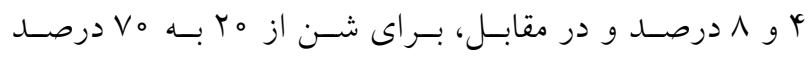
افزايش يافت. اين روند همنو ابا تغييرات ملاحظه شــه بـراى خاكهاى سه رودخانه مورد بررسى است. تغييرات ايجاد شده در اجزاء اندازهاى خاك، باعـث ايجـاد تغييـر در كـلاسهـاى بافت خاك در همه منـاطق مـورد مطالعـه شـده اسـت. نتـايج تحليل واريانس كه در جدول † آملده است، نشان مىدهـد كـه ميانخين متغيرهاى مورد بررسى در سه عمق مختلـف، تفـاوت معنى دار آمارى با يكديخر ندارد. 
جدول ه. مقايسه ميانگين خصوصيات شيميايى و فيزيكى خاك حوضههاى مختلف رودخانهاى

\begin{tabular}{|c|c|c|c|}
\hline \multicolumn{3}{|c|}{ رودخانه } & \multirow{2}{*}{ پِار امتر } \\
\hline كرخه & كارون & جراحى & \\
\hline$r \mathrm{r} / 9 \wedge \mathrm{b}$ & $r Y / O Q b$ & $r q / V G a$ & كربناتها (\%) \\
\hline$r Q / D \circ a$ & IV/AYb & $1 Y / 49 c$ & شورى (dS/m) \\
\hline$\Lambda / Y r a$ & $\Lambda / Y \circ \mathrm{a}$ & $V / 4 V b$ & بِ بهاش \\
\hline
\end{tabular}
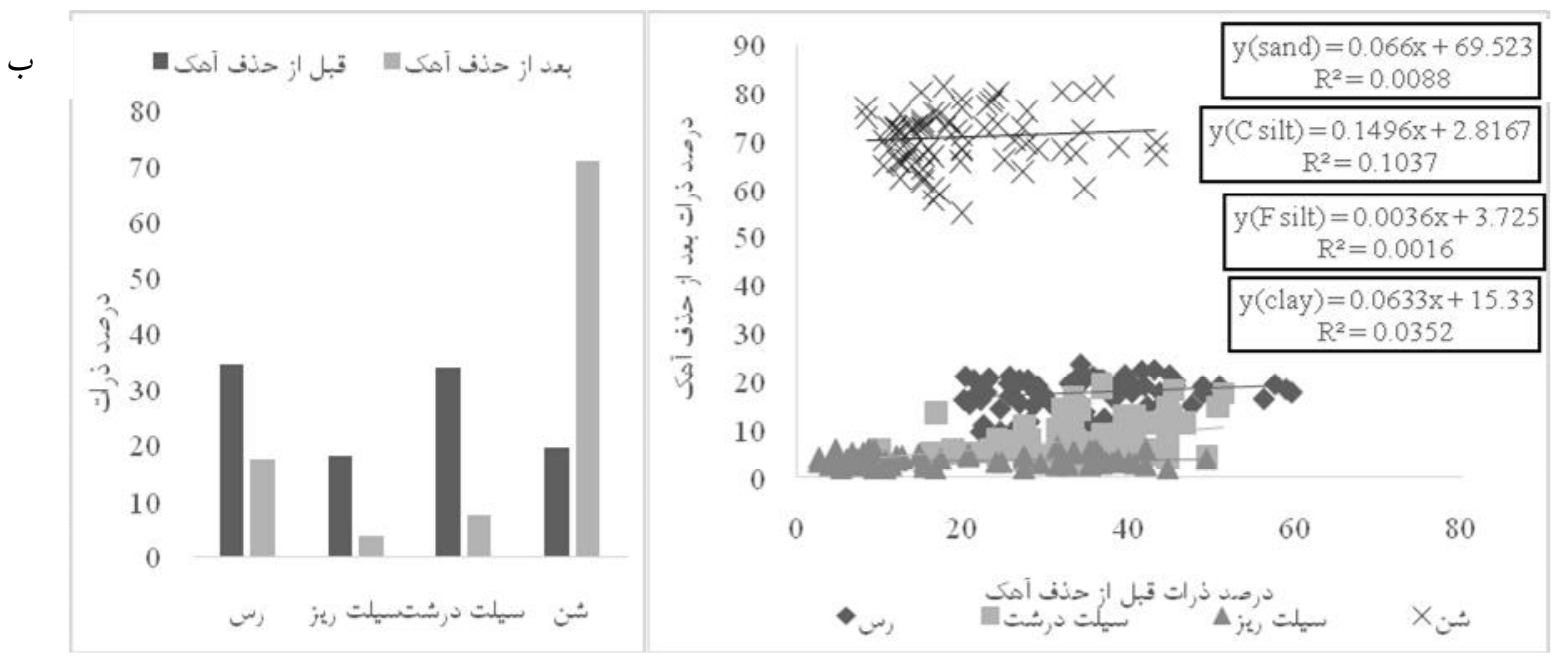

شكل r. الف) مقادير درصد ذرات خاك قبل و بعد از حذف آهك و ب) رابطه و ضريب همبستگى در نمونه خاكهاى رودخانهها

تفاوت معنى دار آمارى ندارند. اين موضـوع مسى توانـــ بـهدليـل تفاوت زياد در سازندهاى زمينشناسى رسوبات منشـأ رودخانـه ها باشد. تركيب سازندهايى تجون ماسه سـنخ بيشـتر از جـنس كوارتز بــوده و كربنـات كمتــى دارد. ايسن درحسالى اسـت كـه سازندهايى تجون آسـمارى و يـا سـروى بـهميـزان بـيش از هو 9 درصد كربنات دارند (r). روابط ركرسيونى براى اجزاى اندازهاى ذرات قبل و بعـد از حذف كربناتها در شكل ب نشان داده شـده اسـت. ايسن نتـايج نشان مىدهد كه بيشترين همبستخى ميـان درصـا انـدازه ذرات قبل و بعد از حذف كربنات در خاكهاى رودخانههـا بـه ذرات

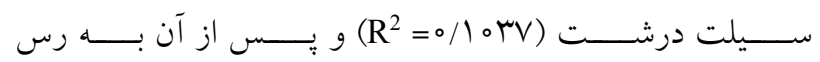
(R2=o/oror) با توجه به اينكه، ضـريب همبسـتخى جـذر ضسريب تعيسين
كارون •90 كيلومتر و طول رودخانه كرخه و جراحى بلهترتيـب

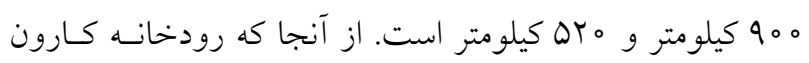
داراى طول بسيار بيشترى از دو رودخانه ديخر است، لذا اثـرات نيروى مكانيكى وارد شده به ذرات خاك و تبديل آنها بـه ذرات در اندازه رس، مى تواند بخشى از علت امر باشـــ. علـت ديخــر مىتواند به اثرات سد بر رسوب ذرات درشت در بشــت آنهـا و

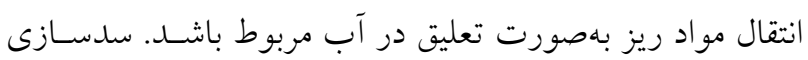
همجنين سبب كاهش سيلابِها و انتقال ذرات درشت به دشت نيز مى شود. نتايج همجينين نشان مىدهد كه اخر جهه ميزان سيلت ريز در خـاكهـاى دو حوضـه جراحسى و كـارون مشـابه بـوده

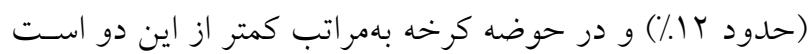
(حدود V/)، ولى در اثر حذف كربناتها، اين ميـزان بـراى هـر سه رودخانه بهميزان قابل ملاحظهاى به يكديكر نزديك شــده و 
برخوردارند. وجود شبكههاى زهكشى مصنوعى، شيوه آبيـارى،

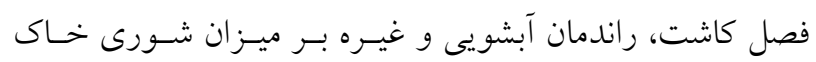

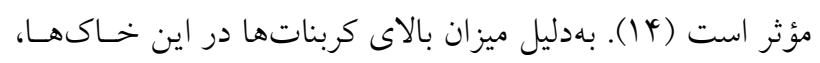

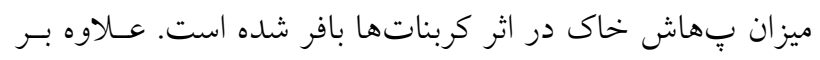

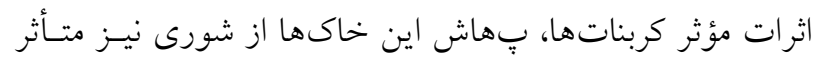

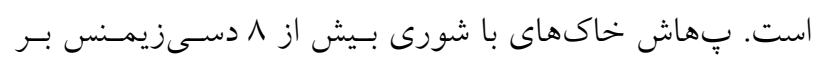

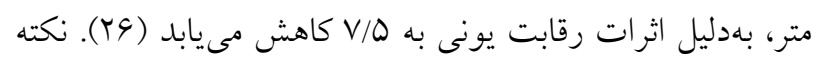

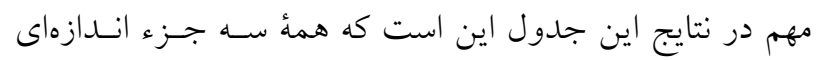
رس، سيلت ريز و درشت در اثر حذف كربناتها كـاهش يافتـه

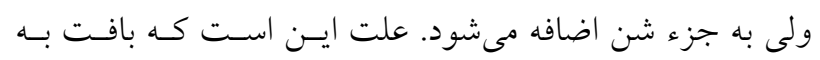

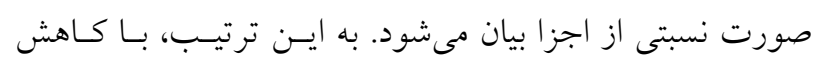
نسبت اجزاى ريز به نسبت جزء درشت اضافه مىشود. بههمسين

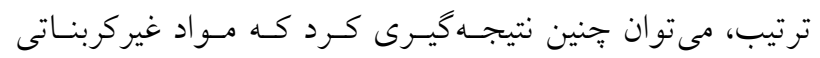

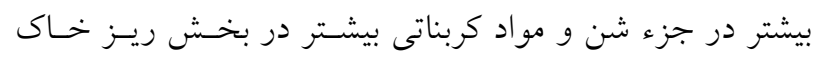

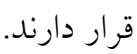

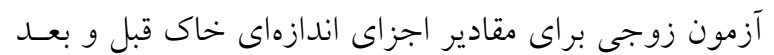

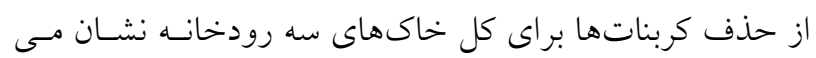

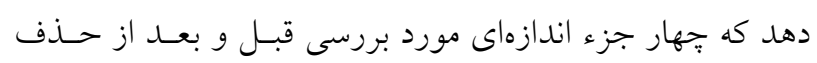

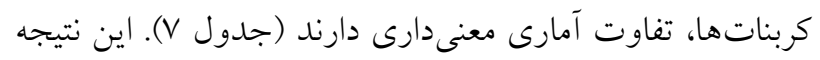

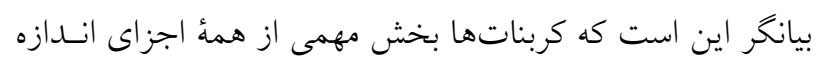

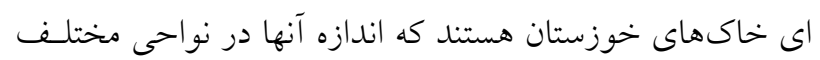

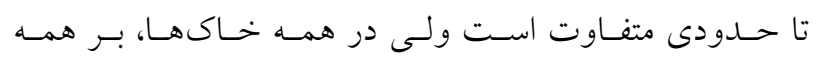
ويزگ كلىاى خاى اثر كذارند.

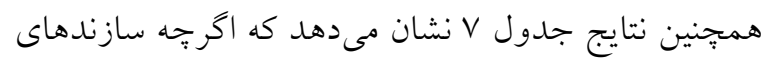

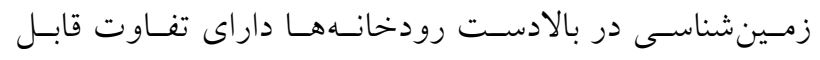

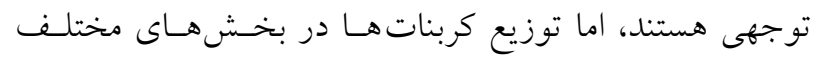

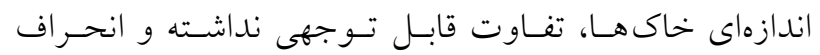

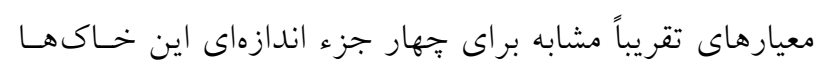
مؤيد اين امر است. نميان.

\section{نتيجه كيرى كلى}

تغييرات ميزان كربنات ها در بخش هاى شـمالى تـا جنـوبى و از
ركرسيونهاى بر آورد شده است بنابر اين ضريب همبستكى بسين

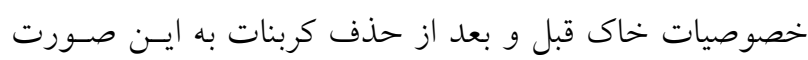

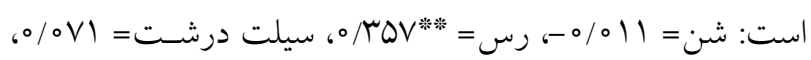

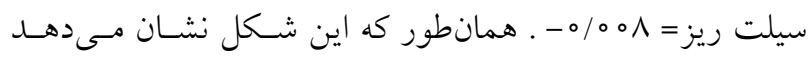

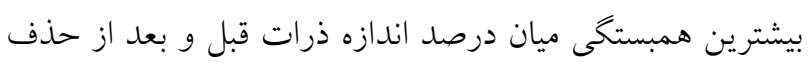

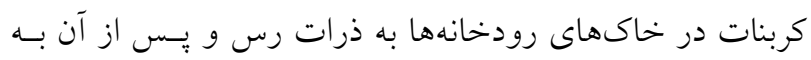
سيلت درشت اختصاص دارد.

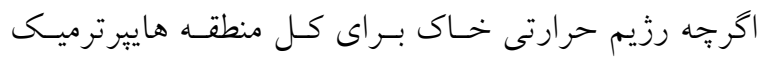

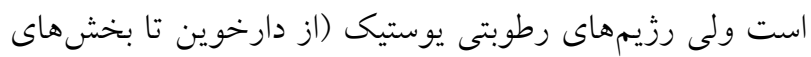

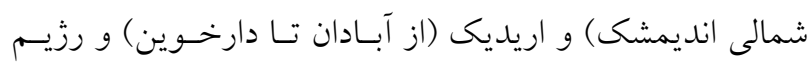

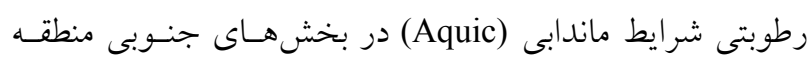
سبب تحولات متفاوتى در خاكها شده است. هم:حنين عمليات آبيارى، سمت و سوى اين تحولات را در اين خاكها نسبت بـهـ

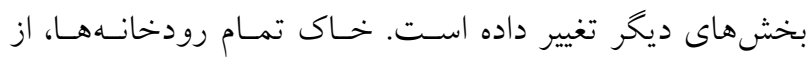

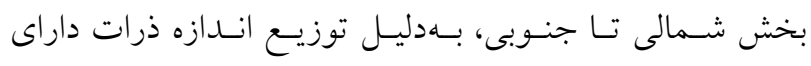

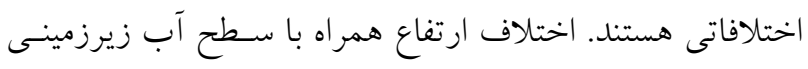

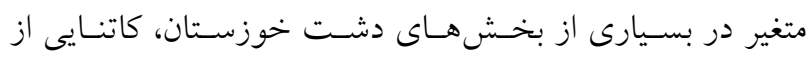
خاكها را از شمال تا جنوب در امتداد مسـير ايسن رودخانـههـا

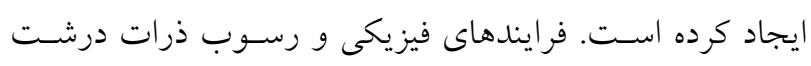
بيشتر در بخشهاى بالادست دشت سبب تشكيل ايسن خـاكهـا

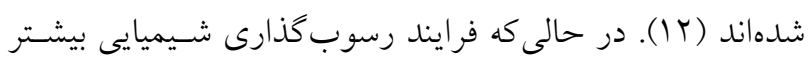

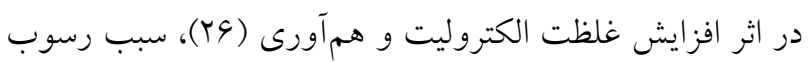

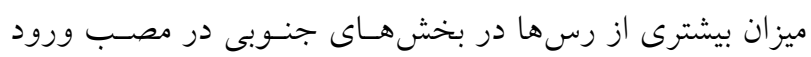

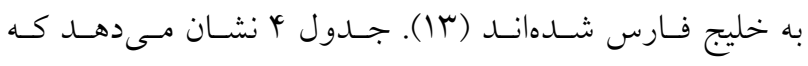

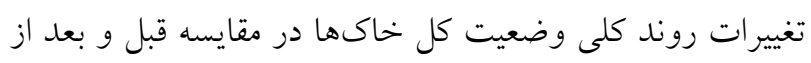

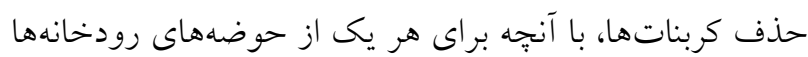
ملاحظه شد، تطابق داشت (جدول \&).

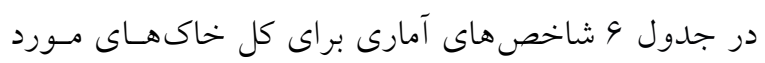

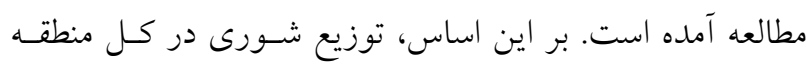

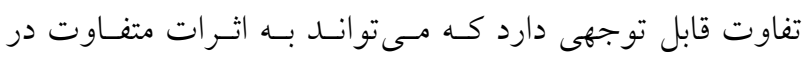

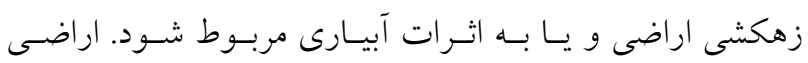

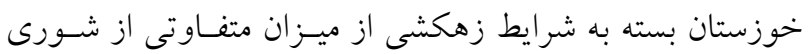


جدول צ. شاخصهاى آمارى براى كل خاكهاى مورد مطالعه

\begin{tabular}{|c|c|c|c|c|c|c|c|c|c|}
\hline ضريب & نما & 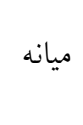 & كشيدگى & جولى & انحر اف & تغحدوده & ميانخين & تعاط & متغير \\
\hline $0 / 19$ & 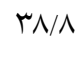 & $r \Delta / \Lambda$ & $\varphi / V$ & $-1 / 9 r$ & $Q / \Delta V$ & $0 / 9-r q / \Lambda$ & ry & TrQ & 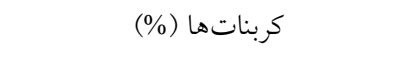 \\
\hline$\circ / 19$ & $r / 4$ & $14 / \pi$ & $T / \Delta Y$ & $1 / 91$ & $19 / 90$ & $\circ / 1-\Lambda \uparrow$ & $11 / 9$ & rTO & شورى (dS/m) \\
\hline.$/ 09$ & $\Lambda / \mu$ & $\wedge / 1$ &.$/ 99$ & $-\circ / 09$ & $\circ / 4 \wedge$ & $\Delta / \mathrm{V}-\Lambda / q$ & $V / 99$ & rTO & بِهاش \\
\hline 每 & $r q / 0$ & 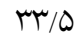 & $-\circ / \mu V$ & $\circ / \mu q$ & $11 / 40$ & $10 / 0-99 / 0$ & $\mu y / 0$ & TrQ & رس قبل از حذف كربناتها (\%) \\
\hline$\circ / T \Delta$ & YI & $1 \mathrm{~V} / \mathrm{D}$ & $\circ / 4$ & $-0 / T \Delta$ & †/M & $\Delta-\mu 1 / \Delta$ & $1 V / 0$ & rTO & رس بعد از حذف كربناتها (\%\%) \\
\hline$\circ / 90$ & 10 & 10 & $0 / \uparrow \Lambda$ & $1 / 9 T$ & $9 / 94$ & $0-M^{c}$ & $10 / 91$ & TrQ & سيلت ريز قبل از حذف كربناتها (\%) \\
\hline$\circ / 09$ & r & r & $\varphi / \Delta r$ & $1 / \wedge 9$ & $r / 14$ & $r-14$ & $r / v q$ & TrQ & سيلت ريز بعد از حذف كربناتها (\%) \\
\hline$\circ / \mu 1$ & r。 & ry & -109 & $-0 / 14$ & $10 / 44$ & $Y-9 Y$ & $M / \Lambda Y^{4}$ & rTD & سيلت درشت قبل از حذف كربناتها (\%) \\
\hline$\circ / \Delta \mathrm{V}$ & r & 4 & $\circ / 94$ & $1 / 19$ & $\varphi / \Delta r$ & $Y-Y^{c}$ & $V / 9$ & rTO & سيلت درشت بعد از حذف كربناتها (\%) \\
\hline$\circ / \Delta Y$ & $14 / 0$ & 19 & $1 / 94$ & $1 / 49$ & $10 / 9$ & $9 / 0-9 \circ / 0$ & $19 / 9$ & rTO & شن قبل از حذف كربناتها (\%) \\
\hline.$/ 09$ & $\sqrt{\mu}$ & $V Y / D$ & $-0 / 00$ & $-o / k y$ & $9 / 4 x$ & $\Delta \circ / \Delta-\Lambda \Delta$ & $V \circ / \Lambda$ & TTQ & شن بعد از حذف كربناتها (\%) \\
\hline
\end{tabular}

جدول V. آزمون زوجى براى مقادير اجزاى اندازهاى خاك قبل و بعد از حذف كربناتها براى كل خاكها

\begin{tabular}{|c|c|c|c|c|}
\hline & & & & متغيرها قبل و بعد از \\
\hline سطح معنى دارى & t & انحراف معيار & اختلاف ميانخين & حذف كربناتها (درصد) \\
\hline$\circ / 000$ & $T r / G$ & $11 / T \Delta$ & $19 / 9 \mathrm{~V}$ & رس \\
\hline$\circ / 0 \circ 0$ & $1 \pi / 9$ & V/RT & $9 / 1$ & سيلت ريز \\
\hline$\circ / 0 \circ 0$ & $r V / 9$ & $10 / \pi \Delta$ & $r Q / Q$ & سيلت درشت \\
\hline \%००० & $-q \psi / r$ & $11 / 9 V$ & $-01 / r$ & شن \\
\hline
\end{tabular}

بهدليل تغيير منشأ مواد مادرى، ميزان ميانخين كربناتهـا كـاهش

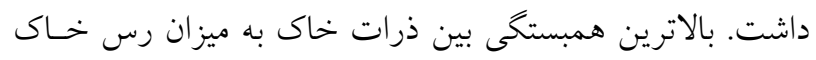

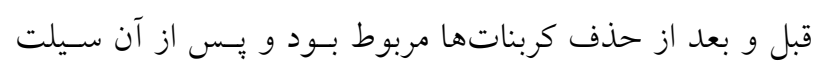

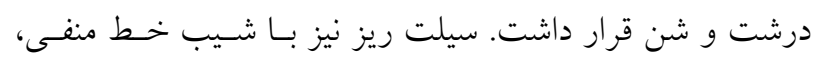

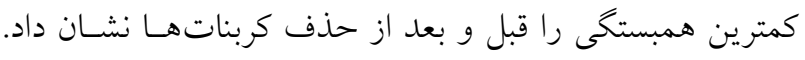

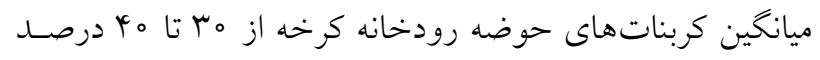

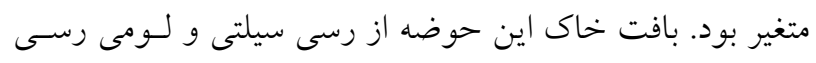
سيلتى بس از حذف كربناتها به لومى شنى تبديل شـــ انـدازه

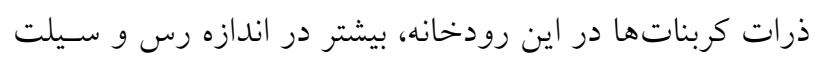

سطح به عمق خاكرخها در رودخانه جراحى مشابه با خاكهـاى

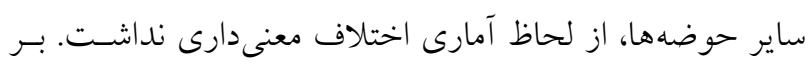

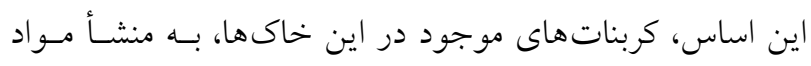

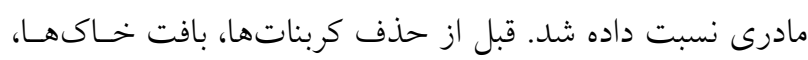

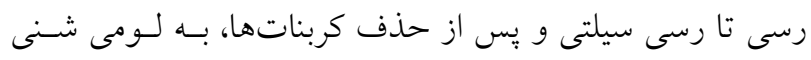

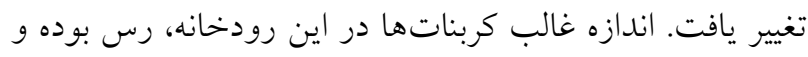
در سطح بعد بهترتيب به اجزاى شن، سـيلت درشـت و سـيلت

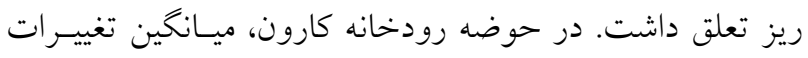

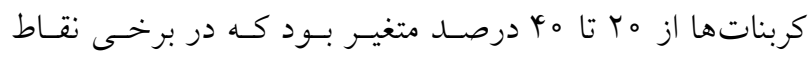




$$
\begin{aligned}
& \text { بود. بيشترين همبستخى ميان درصد اندازه ذرات قبـل و بعـد از آن به سيلت درشت اختصـاص داشـت. نظـر بـه اتـرات ميـزان }
\end{aligned}
$$

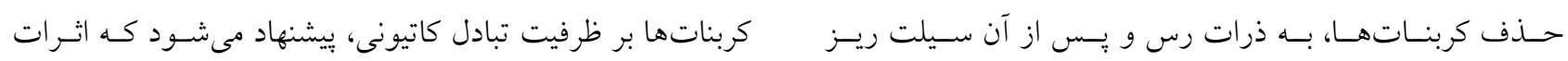

$$
\begin{aligned}
& \text { اختصاص يافت. براى خاى كل رودخانههاى مورد بررسى نيـز، توزيع اندازه ذرات بــر ميـزان ظرفيـت تبـادل كـاتيونى در ايسن } \\
& \text { بافت خاك قبل از حذف كربناتها از سنخين تر (رسسى، سـيلتى خاكها بررسى شود. همجنين از نتايج اين تحقيق، بـراى تعيسين } \\
& \text { رسى و لومى رسى) به بافت سبكتر (لومى شـنى) تغيــر كـرد. كلاس اندازهاى ذرات خاى در سطح فاميـل بـراى ردمبنـدى در } \\
& \text { سيستم آمريكايى و يا تعيين كربناتى بـودن خـاكهـا در كـلاس } \\
& \text { مينرالوزى در سيستم جهانى ردهبندى خاكها استفاده شود. }
\end{aligned}
$$

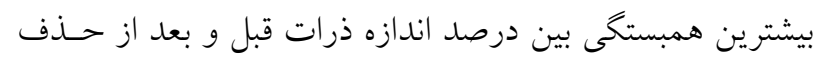

$$
\begin{aligned}
& \text { كربناتها براى كل خاكهاى رودخانهها به ذرات رس و يس از }
\end{aligned}
$$

\section{منابع مورد استفاده}

1. Asgari Hafshejani, N. and S. Jafari. 2017. The study of particles size distribution of calcium carbonate and its effects on some soil properties in Khuzestan province. Iran Agricultural Research 36(2): 71-80.

2. Brown, P. H., R. M. Welch and E. E. Cary. 1987. Nickel: A micronutrient essential for higher plants. Journal of Plant Physiology 85: 801-803.

3. Darvishzadeh, A. 1992. Geology of Iran. Danesh Emroz Organization. Amir Kabir Publisher, Iran. (In Farsi)

4. FAO. 1996. Guidelines: Agroecological zoning. FAO. Soils Bultin 73. FAO, Rome.

5. FAO/UNDP. 1972. Calcareous soils. Report of the Regional Seminar on Reclamation and Management of Calcareous Soils. 27 Nov., Cairo. Egypt.

6. Gee, G. W. and J. W. Bauder. 1986. Particle-Size analysis. PP. 383-411. In: Klute, A. (Eds.), Methods of Soil Analysis, Part 7. Soil Science Society of America. Madison, Wisconsin.

7. Igwe, C. A. and O. N. Udegbunam. 2008. Soil properties influencing water-dispersible clay and silt in an Ultisol in southern Nigeria. International Agrophysics 22(4): 319-325.

8. Jackson, M. L. 1975. Soil chemical analysis-advanced course. University of Wisconsin, College of Agric., Department of Soils, Madison, WI.

9. Jafari, S. 2005. Study of changes in structural, physicochemical, potassium fixation and clay minerals transformation of soils under sugarcane, rotational cropping and non-cultivated soils (Khuzestan), Iran. PhD thesis, Department of Soil Science, Shiraz University, Shiraz. (In Farsi)

10. Jafari, S. 2014. Identification and classification of soils diversity in Khouzestan province. Final Report Research Project, No. 911-81. Khuzestan University of Agriculture Science and Natural Resources. (In Farsi).

11. Jafari, S. and Z. Liu. 2017. Study of characteristics of loess soils in Khuzestan province. Research Project, No. 27/961, Agriculture Sciences and Natural Resources University of Khouzestan, Khouzestan, Iran. (In Farsi).

12. Jafari, S. and H. Nadian. 2012. Study of a toposequence soil series in some soils of Khozestan province. Journal of Water and Soil Science 69: 151-163. (In Farsi).

13. Jafari, S., H. Nadian and M. Chorom. 2011. Study of clay mineralogy in Fars formations group and soil genies from this parent material. Final Report Research Project, No. 86-28. Khuzestan University of Agriculture science and Natural Resources. (In Farsi).

14. Jahani, B., A. Soltani, A. Mohammadi, A. A. Nasseri, P. R. Van Oel and A. Sadeghi Lari. 2017. Reductionf Sugarcane Water Footprint by Controlled Drainage, in Khuzestan, Iran. Irrigation and Drainage 66(5): 884-895.

15. Keshavarzi, A., F. Sarmadian, R. Labbafi and A. Ahmadi. 2011. Developing pedotransfer function for estimating field capacity and permanent wilting point using fuzzy table look-up scheme. Computer and Information Science 4: $130-141$.

16. Khodaverdiloo, H., M. Homaee, M. T. Van Genuchten and D. S. Ghorbani. 2011. Deriving and validating pedotransfer functions for some calcareous soils. Journal of Hydrology 399: 93-99. (In Farsi).

17. Khuzestan Water and Power Authority. 2008. Semi-detailed soil survey studies east and west of North Hofel's land. Sazabpardazan Consult Engineering, Ahvaz. Iran. (In Farsi).

18. Khuzestan Water and Power authority. 2009. Semi-detailed soil survey studies east and west of Karun River's land. Sazabpardazan Consult Engineering, Ahvaz. Iran. (In Farsi).

19. Khuzestan Water and Power Authority. 2011. Semi-detailed soil survey studies east and west of Mekser's land. Sazabpardazan Consult Engineering, Ahvaz. Iran. (In Farsi).

20. Motallebi, E., M. Homaee, Gh. Zarei and S. Mahmoodi. 2011. Studying effect of lime on hydraulic properties using 
pedotransfer functions in, Garmsar. Iranian Journal of lrrigation and Drainage 4: 426-439. (In Farsi).

21. Nelson, R. E. 1982. Carbonate and gypsum. PP. 181-199. In: Page, A. L. (Eds.), Methods of Soil Analysis. Part 2. American Society of Agronomy, Madison, Wisconsin.

22. Pishgir, M. and S. Jafari. 2014. Comparison between potassium and ammonium fixation by clays in different agriculture systems. Journal of water and soil science, Isfahan University of Technology18(69): 237-249. (In Farsi).

23. Rhoades, J. D. 1982. Solouble salt. PP. 167-179. In: Page, A. L. (Eds.), Methods of Soil Analysis: Chemical and Mineralogical Properties (2nd Ed). Agronomy series. American Society of Agronomy and Soil Science Society of America, Madison, Wisconsin, USA.

24. Soil Survey Staff. 1999. Soil Taxonomy. Second Edition. USDA, NRCS.

25. Soil Survey Staff. 2014. Keys to Soil Taxonomy. Second Edition. USDA, NRCS.

26. Sposito, G. 2008. The Chemistry of Soil. 2nd ed., Oxford University Press.

27. Zaker Moshfegh, A. and S. Jafari. 2016. Relation between origion and diversity of caly minerals with dust haze in the surface horizons of some Khuzestan soils. In: Proceeding of 2014 1th International Conference on Dust Haze, Shahid Chamran University of Ahwaz, Ahwaz, Iran. (In Farsi).

28. Zhang, X. C. and L. D. Norton. 2002. Effect of exchangeable Mg on saturated hydraulic conductivity, disaggregation and clay dispersion of disturbed soils. Journal of Hydrology 260: 194-205. 


\title{
Investigating Carbonate Distribution in Particle Size Components of Some Soils of Khuzestan Province
}

\author{
S. Jafari ${ }^{1 *}$, M. Karimzadeh ${ }^{2}$ and A. Abdeshahi ${ }^{3}$
}

(Received: March 28-2020; Accepted: October 19-2020)

\begin{abstract}
Characteristics of most soils in arid and semi-arid regions affected by carbonates. The study aimed to determine the distribution of carbonates in the size components of some soils in Khuzestan province. Upward to the bottom of Karun, Karkheh, and Jarahi rivers were studied at depths of 0-50, 50-100, and 150-100 cm. The results showed that the average amount of carbonates in the soils of the Jarahi river basin (37\%) was significantly different from the amount in the soils of the other two rivers (33\%). Carbonates were observed in all soil size components but the maximum was present in the clay component. The highest regression relationship between soil particles was in the clay component $(0.375)$. The highest percentage of particle reduction after carbonate removal was related to coarse silt particles (0.75). Therefore, the soil texture changed from clay in Jarahi, from clay and silty clay in Karun, and silty clay in Karkheh due to the removal of carbonates to sandy loam. There was no significant difference in the distribution of carbonates at different depths for river soils and all studied soils. The relatively uniform distribution of carbonates in the four components studied in these soils from the surface to the depth showed that the carbonates originated from the parent material, namely alluvial flood sediments of these rivers.
\end{abstract}

Keywords: Carbonate, Clay, Fine silt, Jarahi, Karkheh, Karoon

1. Soil Science Department, Agriculture Sciences and Natural Resources University of Khouzestan, Mollasani, Khouzestan, Iran.

2. Agricultural Economics Department, Agriculture Sciences and Natural Resources, University of Khouzestan, Mollasani, Khouzestan, Iran.

Corresponding author, Email: siroosjafari@asnrukh.ac.ir 